\title{
Impacts of climate change on ski industry
}

\author{
Gilaberte-Búrdalo, $\mathrm{M}^{\mathrm{a}, \mathrm{c}}$; López-Martín, $\mathrm{F}^{\mathrm{b}}$; Pino-Otín, M.R. ${ }^{\mathrm{a}}$ López-Moreno, J.I. ${ }^{\mathrm{c}}$ \\ a- Universidad de San Jorge, - Autovía A-23 Zaragoza-Huesca km 299 Zaragoza, Spain \\ Tfno: (+34) 976060100 \\ b- Gobierno de Aragón, Zaragoza, Spain
}

Paseo María Agustín, 36, edificio Pignatelli, $3^{\text {a }}$ planta, puerta 14, 50071, Zaragoza, Spain.

Tfno: (+34) 976715576

c- Instituto Pirenaico de Ecología, CSIC, Zaragoza, Spain

Avenida de Montañana, 1005. 50059 Zaragoza. Tfno: (+34) 976369393

\begin{abstract}
*corresponding autor
E-mail adresses: mgilaberte@usj.es (M. Gilaberte-Búrdalo), rpino@usj.es (R.Pino-Otín), flopezm@aragon.es (F. López-Martín),nlopez@ipe.csic.es (J.I López-Moreno).
\end{abstract}

ABSTRACT: Ski industry has become one of the main economic activity for many mountain regions worldwide. However, the economic viability of this activity is highly dependent of the interannual variability of the snow and climatic conditions, and it is jeopardized by climate warming. In this study we reviewed the main scientific literature on the relationship between climate change and the ski feasibility under different climate change scenarios. In spite of the different methodologies and climate change scenarios used in the reviewed studies, their findings generally point to a significant impact of climate change on ski industry caused by a reduction in the natural availability of snow as well as a contraction in the duration of seasonal conditions suitable for ski. It emphasizes that the problem is real and should not be ignored in the study and management of tourism in mountain regions. However, there were significant differences in the impacts between different areas. This differences are mainly 
associated to the elevation of the ski resorts, their infrastructures for snowmaking and the various climate models, emission scenarios, time horizons and scales of analysis used. This review highlights the necessity from scientist to harmonize indicators and methodology thus allowing a better comparison of the results from different studies and increase the clarity of the conclusions transmitted to land managers and policy makers. Moreover, a better integration of the uncertainty in the model's outputs, as well as the treatment applied to the snowpack in ski slopes is necessary to provide more accurate indications on how this sector will respond to climate change.

KEY WORDS: climate change; winter tourism; scenario, ski tourism; snowpack

\section{Introduction}

Climate change represents a global issue and its adverse effects constitute a risk to humanity. In spite of uncertainties about, chronological evolution and regional characteristics, the negative effects of climate change on ecosystems and socioeconomic activities are now a measurable fact.

Changes in snow and ice are one of the easiest impacts of climate change to be perceived since they respond rapidly to slight variations in precipitation and temperature (López-Moreno et al., 2008; Nesje and Dahl, 2000). Many studies have reported a decrease in snow thickness and duration in many mountain areas in the world. Thus, Laternser and Schneebeli (2003) and Marty (2008) reported years of unprecedented reduced snowfall after 1980. Less snowfall and snow accumulation was also detected in large parts of North America (Harpold et al., 2012; the Italian Alps (Valt et al., 2005), Slovakia (Vojtek et al., 2003), northern Greece (Baltas, 2007), Spain (López-Moreno, 
2005) and Himalayas (Dar et al., 2013). Changes in snowpack have been more marked at low altitudes (Scherrer et al., 2004).

For most mountain areas it is likely that there will be a decrease in the quantity of accumulated snow, a shortening of the snow cover period, and a decreased and earlier spring freshet (Barnett et al., 2005; Beniston et al., 2003).

In the last 25 years there has been strong growth in mountain tourism, which has become very economically important for many local communities and even at regional or country level. Thus, the economies of these communities are dependent on environmental conditions and factors affecting them, amongst which climate change is of major significance. From the whole range of tourist activities, the ski industry is the one with most economic and demographic influence in mountainous regions. Ski produces direct and indirect revenues related with the functioning of the ski resorts (Steiger,2012). Even this industry has influences on demography development and the economic sector structure (Lasanta et al, 2007).. Even this industry has influences on demography development and the structure of the economic sectors (Lasanta et al, 2007). For this reason, the ski industry is not considered as a simple business managed by private or public companies, but it is a key element to be considered by land managers. In many regions, policy makers and public administrations play a big role for improving the infrastructures for travelling and stay in the ski areas, for promoting the ski with publicity at different levels (schools, media, international fairs, etc) and, in some cases, subsidizing the development of ski resorts or its modernization, mainly for installing snow-making devices. For this reason, the high vulnerability of the ski industry to climate change is a complex, and conflictive issue for planning the future resources of mountain areas. The actions oscillate between an interest for promoting and 
supporting an activity that brings noticeable revenues and opportunities, and the risk to invest resources in a business of uncertain future and with high environmental impact (Koening and Abegg, 1997; Tranos andDavouli, 2014). In this debate, the evaluation and quantification of the impacts of climate change on ski industry in the various mountain regions of the world provide fundamental knowledge, but may also facilitate the development of adaptation or mitigation measures based on solid scientific studies that support decision-making.

Despite the great interest of the topic, the impacts of climate change on this sector started to receive some attention in the late eighties and nineties only (Breiling and Charamza, 1999; Galloway, 1988; Koening and Abegg, 1997; Koening 1998;McBoyle and Wall, 1992). However, the interest has noticeably increased in the last years at the same time of its economic and social importance.

In this paper, we conduct an extensive review of selected scientific literature on the impacts of climate change on ski industry. The main results reached in this field for different ski resorts located in Europe, North America, Asia and Oceania are summarized in the following section. They serve as basis to develop an overall discussion of the results, and to discuss about the major needs for further research in this topic (section 3) in order to improve the accuracy and robustness of the conclusions and to enhance the usefulness of the results for the ski sector and policy makers.

The geographical areas encompassed by the review are shown in Figure 1, which includes an enlargement for the European area because of the high density of study locations in this continent. 




Figure 1: Studies location

\section{Impacts of climate change on ski areas}

\subsection{Europe:}

One of the first studies of the impacts of climate change on mountain tourism in Europe was carried out by Koenig and Abegg (1997). They investigated winter tourism in the Swiss Alps and highlighted the strong dependence of winter tourism on climate conditions, and on the availability of sufficient snow to support snow-based sports. The study stemmed from a period in the 1980s when the scarcity of snow over three consecutive years resulted in enormous economic losses in accommodation and transport sectors. Koenig and Abegg (1997) assessed what consequences a rise in temperature, would have on the future availability of adequate snow conditions. The 
results showed that a rise of approximately $0.3^{\circ} \mathrm{C}$ would result a rise on $300 \mathrm{~m}$ in the altitude of permanent snow in the central Alps and by $500 \mathrm{~m}$ in the Pre-alpine region. Further a delay in the first snowfall of the season, and a reduction in the duration of snow cover by up to one month is expected. Under these climatic conditions the availability of snow will only be reliable in ski resorts located above $1200 \mathrm{~m}$, which in the Swiss Alps includes $85 \%$ of the resorts. However, if the temperature rises by $+2^{\circ} \mathrm{C}$ the snowline will move up to $1500 \mathrm{~m}$, and under these conditions only $63 \%$ of the ski slopes will be feasible. Ski resorts at higher altitudes, including those of the Grisons canton and Valais, would have good skiing conditions even with a temperature rise of $+2{ }^{\circ} \mathrm{C}$. In a further study in the same region, (Elsasser and Bürki, 2002) indicated that with an upward shift in the snowline to $1800 \mathrm{~m}$ a.s.1., only $44 \%$ of the ski runs and $2 \%$ of the ski lifts will be operable.

These impacts suggest that there will be a greater concentration of tourists in higher altitude areas, and consequent environmental problems related to increasing pressure on the water resources (supply), pollution, impacts on the flora and fauna and wastewater disposal systems(Koenig and Abegg, 1997), and also problems derived from soil and landscape modification.

Abegg et al. (2007) confirmed this previous prognosis, and in the OECD study reported the consequences of warming of 1,2 and $4{ }^{\circ} \mathrm{C}$ in the Swiss Alps. Their analyses indicate that 159 of a total of 164 Swiss ski resorts were viable, but this would drop to 142,129 and 78, with an temperature increase by 1, 2 and 4 respectively. Despite this, Gonset (2013) stated that the ski industry is expected to be less affected in Switzerland than in the other European alpine countries. 
Beniston et al. (2003) framed the sensitivity of the thickness and duration of snowpack in Switzerland with the simulated climate change projections from Regional Climate Models (RCMs) for the time slice 2071-2100. Results suggested a 90\% reduction in snow quantity at an altitude of $1000 \mathrm{~m}, 40-60 \%$ reduction at $2000 \mathrm{~m}$, and $30-40 \%$ reduction at $3000 \mathrm{~m}$, all of which having negative consequences for ski tourism in the area. With respect to the duration of the snow season, for every $1{ }^{\circ} \mathrm{C}$ average rise in winter temperature the snow cover would be reduced by an average of 15-20 days in the Alps. With a rise of $4{ }^{\circ} \mathrm{C}$ the duration of snow cover would be reduced by about $50-$ 60 days at altitudes of 2000-2500 m, and between 110-130 days at altitudes of approximately $1000 \mathrm{~m}$. More recently, Uhlman et al. (2009) confirmed the uncertain future of Swiss ski resorts located at low altitudes, although they noted that there are marked local differences associated with the effect of slope and orientation on the sensitivity of the snow cover to climate change.

In the case of the Italian Alps, Mercalli et al. $(2006,2007)$ reported that a rise of $2^{\circ} \mathrm{C}$ or $4^{\circ} \mathrm{C}$, would cause the snow line to rise by 300 and $600 \mathrm{~m}$, respectively (EURAC, 2007). Moreover, it was reported that a rise in the current temperature of less than $1^{\circ} \mathrm{C}$ may cause serious loss of snow cover at altitudes $<1400 \mathrm{~m}$, and that there would be a $35 \%$ reduction in the annual duration of the snow cover for every $1^{\circ} \mathrm{C}$ rise in temperature. Less extreme but noteworthy effects will occur at higher altitudes, where for every $1{ }^{\circ} \mathrm{C}$ rise in temperature there will be an average loss in snow depth of $15 \%$ at approximately $1850 \mathrm{~m}$, and $12 \%$ at $2300 \mathrm{~m}$. Ski resorts in the Italian Alps are generally located at quite high altitudes. However, this does not preclude them from the impacts of climate change. Based on the assumption that for every $1{ }^{\circ} \mathrm{C}$ rise in temperature the permanent snow line for skiing will rise by $150 \mathrm{~m}$, out of the 167 ski resorts in Italy, 
131 (located higher than $1650 \mathrm{~m}$ ) will remain viable for winter sports. If temperature rise $2^{\circ} \mathrm{C}$, will be 88 resorts (higher than $1800 \mathrm{~m}$ ) viable, and if the temperature rise $4^{\circ} \mathrm{C}$ only 30 resorts (higher than $2100 \mathrm{~m}$ ) will remain viable (EURAC, 2007).

The effect of climate change on the ski industry in Austria has been intensively analyzed in the last years in alpine region, Breiling and Charamza (1999) developed a statistical model including data on temperature, precipitation and snow cover, and concluded that at an altitude of $2000 \mathrm{~m}$ a temperature rise of up to $2^{\circ} \mathrm{C}$ with no change in precipitation would have no major consequences for the ski resorts, but at middle altitudes a rise of only $0.8^{\circ} \mathrm{C}$ would have serious consequences. Steiger and Mayer (2008) and Steiger (2011) noted the importance of artificial snowmaking to reduce the effects of climate change on sky resorts feasability, although in some cases this will not be sufficient. Moreover, the potential number of days with optimal humidity and temperature conditions for making artificial snow will be reduced by approximately $33 \%$ if there is a temperature rise of $+2^{\circ} \mathrm{C}$. In a subsequent study, Steiger (2012) probed that the dependency on natural snow conditions has declined over recent years because of improved snowmaking techniques, although this has involved substantial increases in cost and investment, and ultimately this may directly affect the tourist affluence due to the rise of lift tickets price. Steiger and Abegg (2013) recently analyzed how climate change might affect winter tourism in Austria. This study was mainly based on three criteria: the 100-day rule (based on the assumption to be considered reliable ski resort needs a minimum of 100 days per season with a snowpack deeper than $30 \mathrm{~cm} 7$ out of 10, winters Witmer, 1986); the ski season beginning on December 8; and the availability of sufficient snow during the Christmas holidays. The results of this study show that only $43 \%$ of a total of 228 ski areas met these criteria during the reference 
period (1961-1990). Based on the 100-day rule, increases of 1,2 and $4{ }^{\circ} \mathrm{C}$ would reduce total available areas for skiing and snowmaking by 81,57 and 18 respectively. Under a $+2{ }^{\circ} \mathrm{C}$ temperature increase scenario more than $50 \%$ of the ski areas will have to increase snowmaking by 100-199\%.

Moen and Fredman (2007) found that in Sweden during the period 1961-1990 the temperature increased by an average of $2^{\circ} \mathrm{C}$, the precipitation remained stable, but the snow cover decreased by $8 \mathrm{~cm}$ depth. This resulted in a reduction of 5 days in the potential ski season, (measured as the number of days with at least $30 \mathrm{~cm}$ of snow depth, Elsasser and Bürki, 2002; Scott et al., 2003). The same study presents a detailed analysis for the region of Sälen (southwest Sweden). under the A2 (about $+5^{\circ} \mathrm{C}$, and $+45 \%$ precipitation) and $\mathrm{B} 2$ (about $+2.5^{\circ} \mathrm{C}$, and $+15 \%$ precipitation) regional climate change scenarios. It showed the amount of snowfall would be reduced by $66 \%$ under scenario A2 and 44\% under scenario B2.The duration of the ski season, which has been 162 days on average over recent years, will be reduced by 96 days under scenario A2 and 64 days under scenario B2.

López-Moreno et al. (2009) estimated that in the Pyrenees over the time period 20702100 there would be a decrease of $78 \%$ in the duration of snow cover at $1500 \mathrm{~m}$ under climate change scenario A2 (projected temperature increase in this study ranges from $2.4^{\circ} \mathrm{C}$ to $4.1^{\circ} \mathrm{C}$ with a mean change of $3.1^{\circ} \mathrm{C}$ ), and a decrease of $20 \%$ at $3000 \mathrm{~m}$. Under climate change scenario $\mathrm{B} 2$ (temperature increase from $0.9^{\circ} \mathrm{C}$ to $2.3^{\circ} \mathrm{C}$, with a mean change of $1.3^{\circ} \mathrm{C}$ ), they forecast a decrease of $44 \%$ in the duration of snow cover at 1500 $\mathrm{m}$ and $11 \%$ at $3000 \mathrm{~m}$. Under scenario A2 they predicted a reduction of $70 \%$ in snow volume at $1500 \mathrm{~m}$ and an $11 \%$ reduction at $3000 \mathrm{~m}$, whereas for B2 they predicted the reduction would be $32 \%$ at $1500 \mathrm{~m}$ and $5 \%$ at $3000 \mathrm{~m}$. 
More specifically, for the Aragonese Pyrenees (Spain) under climate change scenario A2 for the time horizon of 2040 it was concluded that the resorts will generally continue to be viable, but that low altitude areas will require artificial snowmaking because of the higher temperatures (Ribalaygua et al, 2013), especially during the month of March (Estudio sobre el sector de la nieve en Aragón, 2009). This report also indicated that the situation will worsen severely by the second half of the century. Thus, It was estimated that only resorts at an altitude of $1750-1800 \mathrm{~m}$ or higher has the snow viability guaranteed.

Pons et al. (2012) used the snow cover change scenarios developed by López-Moreno et al. (2009) to simulate skiability at three ski resorts (Arcalís, Pal-Arinsal and GrandValira) in Andorra at the end of the 21st century under scenarios B2 and A2. Two scenarios assumed an increase of $+2^{\circ} \mathrm{C}$ and $+4^{\circ} \mathrm{C}$, respectively, and another two assumed the same temperature increase but incorporated artificial snowmaking. They found that based on natural snow availability only for the lowest areas of Pal-Arinsal would there be a contraction $(30 \%)$ in the duration of the ski season with a temperature increase of $+2{ }^{\circ} \mathrm{C}$, and with the introduction of artificial snowmaking the ski season length would be reduced by $25 \%$. Under the $+4^{\circ} \mathrm{C}$ temperature increase scenario all three resorts would be seriously affected: the length of the season would be reduced by 95\% at Pal-Arinsal, by $17 \%$ at GrandValira, and by $27 \%$ at Arcalís.. . The general conclusions of this study indicate that snowmaking will not be able to completely overcome the problems resulting from a temperature increase in the lower altitude skiing areas of Andorra (Pons et al., 2012).

2.2 North America: 
In North America, studies on the impact of climate change on ski industry were initiated earlier than in other parts of the world. The first studies, carried out in Canada and the United States in the late 1980s (Lamothe and Périard, 1988; Lipski and McBoyle, 1991; McBoyle and Wall, 1987), projects reductions exceeding 50\% in the skiable days.. These projections overestimated the impact of climate change, primarily because they did not take account of mitigating measures including snowmaking technologies, which were now fully integrated into the operation of ski resorts (Scott, 2006).For Quebec, most recent studies indicate that the use of snowmaking has considerably reduces the vulnerability of these areas to climate change. Based on the IPCC climate change scenarios for 2020 and 2050, it was found that under scenario B2 (the lower temperature increase scenario) the reduction in snow depth will be $8 \%$ by $2020\left(+1.4-1.6^{\circ} \mathrm{C}\right)$ and $26 \%$ by $2050\left(+1.9-2.3^{\circ} \mathrm{C}\right)$, and will particularly occur during March, at the end of winter (Scott et al., 2007). For the higher temperature increase scenario (A1), the reduction will be about $29 \%$ by $2020\left(+2.8^{\circ} \mathrm{C}\right)$ and $75 \%$ by $2050\left(+7.4-7.9^{\circ} \mathrm{C}\right) .$. Under scenario B2 the ski season length will decline by $0-2 \%$ by the 2020 s and by $4-7 \%$ in the 2050s, while for the A1 scenario the reduction will be $13-15 \%$ by the 2020 s and approximately $30 \%$ by the 2050 s. The need for artificial snowmaking under scenario B2 will increase by $15 \%$ by 2020 and $30 \%$ by 2050 ; for scenario A1 the increase will be $43 \%$ by 2020 and $131 \%$ by 2050 .

In the Ontario region of Canada (specifically the Horseshoes ski resort) resorts are (in contrast to other areas) predicted to continue to be viable under a warmer climate, but assuming an increasing snowmaking capabilities, because with the current capabilities the average ski season is projected to decrease by $0-16 \%$ (B2-A2) in the $2020 \mathrm{~s}, 7-32 \%$ 
(B2-A2) in the 2050s and $11-50 \%(B 2-A 2)$ in the 2080s, depending on the climate change scenario imposed (Scott et al., 2003).

In a study in the northeastern United States, Dawson et al. (2009) used the analogue approach to analyze the impact of climate change on the duration and permanence of the snowfall, and the effect of this on tourist demand for the time period 2040-2069. To represent an A1 climate change scenario they chose the 2001-2002 season, during which record temperatures of $+4.4^{\circ} \mathrm{C}$ above long-term average were exceeded (based on the period 1960-1990). To represent a B1 climate change scenario they chose the winter 1998-1999 as the reference; during this winter the temperature was $+2.7^{\circ} \mathrm{C}$ above the base period (1960-1990), and there was a $40 \%$ decrease in natural snow. The season was reduced by 5 days for the B1 climate change scenario and 15 days for the A1 scenario. The tourist demand will drop $11,6 \%$ in A1 scenario and $10,8 \%$ in the B1 scenario.

In a later study of the same area, Dawson and Scott (2013) used climate change scenarios A1 and B1 for the time frames 2010-2039, 2040-2069 and 2070-2099. They found that for the time period 2010-2039 only 55\% (B1) and 54\% (A1) of a total of 103 ski resorts would be viable (under the 100-day rule). The percentages were $54 \%$ (B1) and $40 \%$ (A1) for the period 2040-2069, and 45\% (B1) and 29\% (A1) for the period 2070-2099. Another parameter considered in this study was the ability to exceed $75 \%$ of probability to be operable during the economically important Christmas-New Year holiday period. The results showed for the 2010-2039 period only 44\% (B1) and 44\% (A1) of resorts would be operable over this period. The probabilities declined to $35 \%$ (B1) and 26\% (A1) for the period 2040-2069, and 33\% (B1) and 7\% (A1) for the 20702099 period. Based on the combination of the two parameters considered (100-day rule 
and $75 \%$ operational probability for the Christmas period), only 41 (A1) and 42 (B1) of a total of 103 ski resorts would be viable for the 2010-2039 period, 34 (A1) and 41(B1) for the 2040-2069 period, and 30 (A1) and 35 (B1) for the 2070-2099 period.

\subsection{Asia:}

There are relatively few studies on climate change and tourism for the Asian continent. Demiroglu (2000) analyzed 12 of the largest ski areas in Turkey based on climate change scenarios of $+1^{\circ} \mathrm{C}(2025),+2^{\circ} \mathrm{C}(2050)$ and $+4^{\circ} \mathrm{C}(2100)$, and the assumption of an upward movement of $150 \mathrm{~m}$ in the line of snow reliability for every $1^{\circ} \mathrm{C}$ rise in temperature. 6 of the 12 resorts are not operable with $a+1^{\circ} \mathrm{C}$ temperature rise. With a $+2^{\circ} \mathrm{C}$ rise only 2 resorts could operate, and under a $+4^{\circ} \mathrm{C}$ increase none of the resorts analyzed will remain operable (Demiroglu, 2000).

Fukushima et al. (2002) developed a statistical model of snow conditions for Japan, to quantify how future climate change might affect tourist demand in the principal ski areas. First, they built a model for simulating snow depth based on the water and heat budgets. Afterwards, they statistically related the number of daily skiers with the simulated snow depth. They concluded that with a $+3^{\circ} \mathrm{C}$ temperature increase and no change in precipitation there would be a reduction of $30 \%$ in the number of skiers visiting ski areas.; exceptions were the Hokkaido region in the north, and high elevated areas on the main island. On the other hand, in the south of the country and in low elevation areas, the number of skiers could decrease by up to $50 \%$.

For the Yongpyong resort in South Korea, Heo and Lee (2008) reported that since 1990 the snow cover depth and snowfall have decreased by $16 \%$ and $4 \%$, respectively. Based on climate change scenario A1B for the 90-year period 2011-2090, they estimated that the ski season length will be reduced from the current 120 days to 105 days for the 
period 2010-2030, to 84 days for the period 2030-2060, and to 61 days for the period 2060-2090. Thus, between 2010 and 2090 the ski season length will decline by $42 \%$.

Artificial snowmaking is an essential tool for the viability of all ski resorts in Korea, and particularly for the Yongpyong resort. Based on a temperature of $-3^{\circ} \mathrm{C}$ and relative humidity of $60-80 \%$ being the ideal atmospheric conditions for artificial snowmaking (during the months of December to March), under climate change scenario A1B the optimal number of days for snowmaking in the period 2070-2090 will be reduced to 30 days from the 51 days for the 1970-2008 analysis period (Heo and Lee, 2008).

\subsection{Oceania}

Australia and New Zealand are the only regions in the southern hemisphere from which there are scientific reports on the effect of climate change on ski resorts and ski tourism. Koenig (1998) analyzed the impacts of different regional climate scenarios on the Australian Alps. Based on a temperature increase of $+0.3^{\circ} \mathrm{C}$ and the 60 -day rule (natural snow-cover duration at least 60 days per season), all the ski resorts analyzed (9) will be viable in 2030 except for one. Under the worst-case scenario $\left(+1.3^{\circ} \mathrm{C}\right.$ temperature increase), skiing will only be possible at one resort. Under the best-case scenario for 2070 (a temperature rise of $+0.6^{\circ} \mathrm{C}$ ), six ski resorts will exist still; but in the worst-case scenario $\left(+3.4^{\circ} \mathrm{C}\right)$ no one of the resorts will remain viable.

In a more recent study of the Australian Alps, Pickering and Buckley (2010) analyzed the number of days with at least $1 \mathrm{~cm}$ of snow cover at 20 locations within the ski resorts, under a moderate climate change scenario of $+1^{\circ} \mathrm{C}$. By 2020 only seven of the 20 locations $(35 \%)$ are expected to maintain at least $1 \mathrm{~cm}$ of natural snow cover for 70 days or more, two locations will maintain this cover for 60-70 days, and 11 locations 
will maintain this cover for $<60$ days. The results of this study indicate that under a $1^{\circ} \mathrm{C}$ temperature rise scenario many ski resorts will not be viable with only natural snow conditions. The dependence on artificial snow will increase continuously, and it is possible that many resorts will not be able to meet the expense, and access the increased volume of water required. The most recent study in the southern hemisphere, conducted by Hendrikx et al. (2013), involved a comparative analysis of future impacts in Australia and New Zealand using in both places the same method of analysis. They considered three Global Climate models and the mid-range emissions scenario A1.The results show that in New Zealand at lowest elevation (the most sensitive sites) the number of days with snow depths equal to or greater than $30 \mathrm{~cm}$ will be reduced from 125 currently to 111 days by 2040, and 68 days by 2090; in Australia it is currently 124 days and will reduce to 85 days by 2040 and 21 days by 2090 (this results are the mean values obtained from the three global climate models)

\section{Overall assessment and conclusions}

Most reviews of the impact of climate change on the ski industry have used climate change scenarios or fixed thresholds of warming in models for estimating future changes in snow conditions (especially snow depth and duration), and to assess how climate change might affect the viability of ski resorts in various mountain areas. Despite the relatively large number of studies addressing this issue in many different geographic areas, it is very difficult to compare the results because of the variety of methodologies used, the different parameters considered in assessing the viability of the ski industry under climate change conditions, and the various climate models, emission or warming scenarios, time horizons and scales of analysis used. Thus, among all the studies reviewed here (summarized in Table 1) few have been appropriate for direct 
comparison (Fig. 2). Adoption of common terminology, methods and indicators are necessary to facilitate comparison among different geographical areas, thus increasing the usefulness for decision makers of the results of studies in this field (Tranos and Davoudi, 2014). Thus, the regular consideration of indicators such as changes in the length of the ski season (considering different elevations and slope aspects within the specific ski resorts) and the reduction in number of skiers would help to compare climate change impacts on this economic sector. Figure 2 shows the decrease in the number of ski days and the percentage of ski resorts within a particular region that should be closed as a function of various scenarios of climate warming. The studies from which Figure 2 was derived, and the other studies reviewed, highlight how sensitive the ski industry is to increasing temperature, but also the large variability in skiability in response to similar warming rates. For example, changes in the number of ski days in response to climate warming at two resorts located in Andorra differed markedly (Fig. 2A; Pons et al., 2012). These differences can be largely explained by the average altitude of the resorts, or the latitude of the mountain regions involved. Thus, colder areas (because of high altitude or latitudinal location) are less affected by climate change, or may even benefit through spillover from lower-altitude resorts that are more vulnerable to the effects of climate change (Dawson and Scott, 2010; Koenig and Abegg, 1997; Scott et al., 2008).

In addition to the influential effect of increasing temperature on the ski industry, the evolution of future precipitation may partially balance or exacerbate the effect of climate warming on snowpack duration and accumulation (López-Moreno et al., in press), and hence affect the skiability of a given resort or region. However, the projections for the future vary greatly, even over very short distances, and are subject to 
much greater uncertainty than for temperature (Dequé et al., 2007). Thus, assessment of the future of the ski industry should include the effect of changing precipitation together with warming effects, but fully account for uncertainty. In this way, decision makers would not considered specific results of climatic change, but with a range of scenarios ranked by the likelihood of their occurrence. 

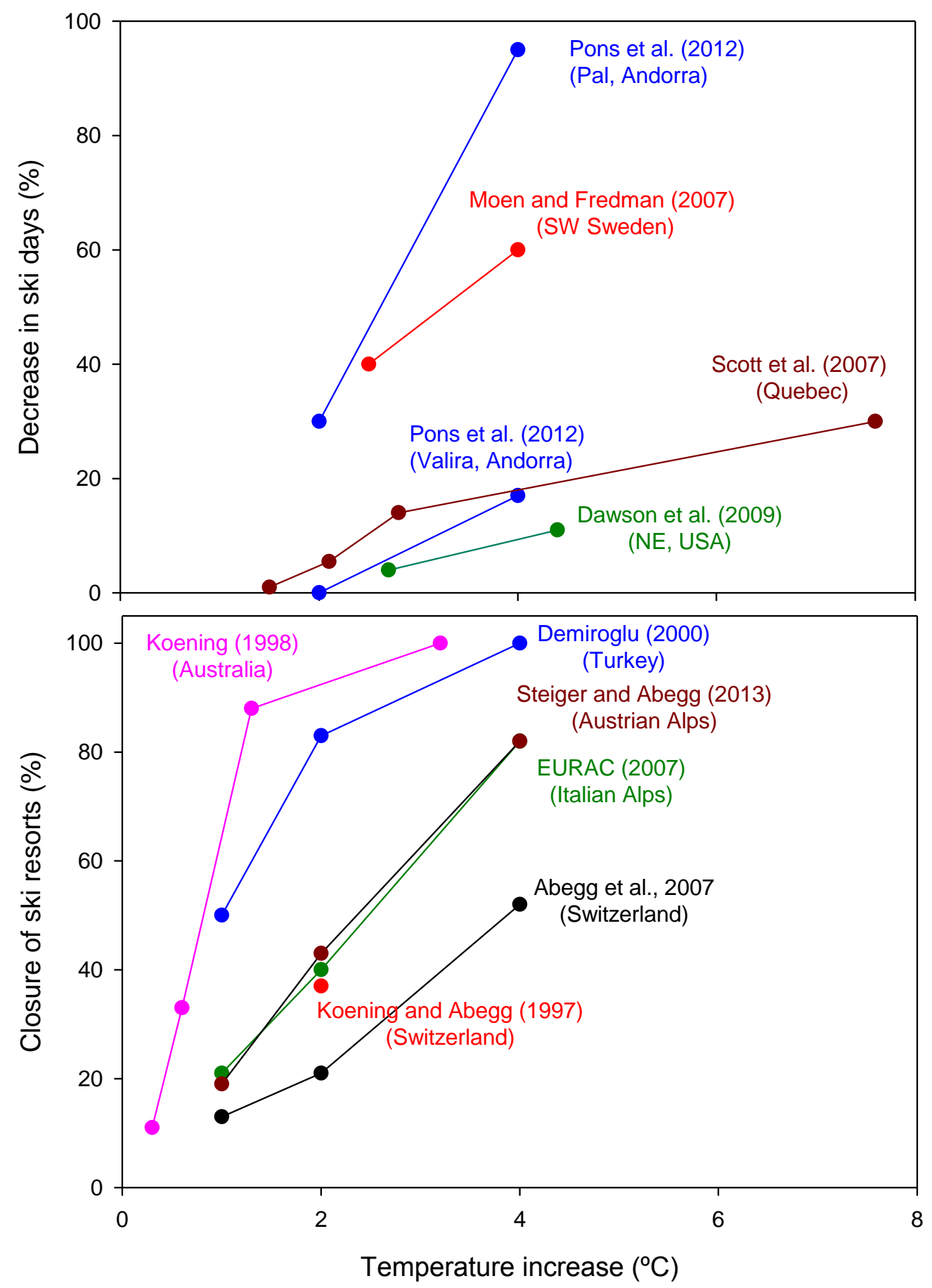

Figure 2. Reduction in the number of ski days and the percentage closure of ski resorts in various regions as a function of temperature increase. 
Most of the reviewed studies assessed the viability of ski resorts under changing climate based on the simulated snowpack under natural conditions, and then used established criteria to assess the economic viability of the ski areas in determining the potential need for resort closure or a shorter ski season. These approaches are useful but require careful interpretation. Some of the established criteria for skiability, including the $30 \mathrm{~cm}$ threshold and a minimum annual operation time of 100 days (; Abegg, 1996; Abegg et al., 2007; Dawson and Scott, 2007, 2010; Elsasser and Bürki, 2002; Koening and Abegg, 1997;; Moen and Fredman, 2007; Pons et al., 2012; Scott et al., 2003;; Scott et al., 2007; Steiger, 2010; Wittmer, 1986), a 75\% probability of being open during Christmas holidays (Dawson and Scott, 2013; Scott et al., 2008), or being operational on 8 December, the Christmas holidays and New Year (Steiger, 2013) cannot be systematically applied to all areas. There are other local factors to consider as the specific physical and technical characteristics of the resorts (e.g. roughness of the ski slopes and the location of the chair lifts), or the economic framework within which ski companies develop their activities (e.g. the number of employees, the price of water and energy, and the presence of public subsidies). Consequently, greater interaction between scientists and managers of ski areas is needed. Furthermore, many studies have only considered ski conditions based on the natural snowpack, whereas studies that have considered snowmaking in their simulations have highlighted this as a useful tool in reducing the impacts of climate change on ski businesses. However, various limitations associated with snowmaking have been reported. At lower altitudes at ski resorts there are fewer nights suitable for snowmaking, so more snowmaking guns are needed, and consequently there is more consumption of water and energy, and higher costs (Pickering and Buckley, 2010). Furthermore, increased water consumption for artificial 
snowmaking may generate conflict among mountain communities and various agricultural, urban residential, power generation and other industrial uses (Morrison and Pickering, 2013; Pickering and Buckley, 2010;). Consequently, ski companies and public bodies need to consider with caution the implementation of this adaptation tool (Hopkins, 2014; Vanham et al., 2009). In addition to snowmaking, the management of snow to improve its quality and duration on ski slopes is highly complex. The processes applied to the snow, including preparation of the ground, artificial snow production, redistribution and compaction, and modifications to snow roughness and its aerodynamic characteristics are encompassed in the term 'snow crop'. These techniques markedly affect the density and thermal conductance of the snowpack, and the exchange of energy between the snow surface and the atmosphere (Fauve et al., 2002), as well as affect on the sensitivity of the snowpack to climate warming. However, no studies to date have considered physical transformations of the snowpack in developing future scenarios of ski conditions. We believe this aspect will need to be addressed in the near future to enable more accurate scenarios concerning the viability of ski resorts under changing climate to be provided to ski companies, government agencies and decision makers.

This review has highlighted evidence that climate change is a major threat to tourism through the closure of ski resorts in many mountain regions. However, despite the economic importance of skiing for many mountain regions, less snow does not necessarily imply the end of winter sports and tourism in these regions. Mountain areas are valuable landscapes and offer many attractions for tourists; these can offset, at least in part, the economic losses resulting from a worsening in the conditions for skiing. For example, the 2008-2009 winter season in the Black Forest was profitable from the point 
of view of tourism, despite the fact that this was the warmest period since 1961 (Endler and Matzarakis, 2011). In this regard, the development of activities complementary to ski tourism, such as snowmobiling, dog sleighing and ice fishing, can be developed, although these are also dependent on snow cover (Moen and Fredman, 2007). Yearround tourism not based on snow availability, such as hiking, kayaking and canyoning, have become important tourist options in mountain areas (Tranos and Davoudi, 2014). However, all are dependent on the availability water, and may be seriously jeopardized by climate change. Few studies have considered how climate change might affect these other types of tourism, so it will be of importance add the assessment of theeffects of climate change on these other activities to the impacts on the ski industry. Overall assessment in this regard may provide robust tools to plan the management of tourism activities and devise strategies to minimize the negative effects of climate change in mountain communities.

\section{Acknowledgements}

This study was supported by the research CGL2011-27536/HID, Hidronieve, financed by the Spanish Commission of Science and Technology and FEDER; and CTTP1/12 “Creación de un modelo de alta resolución espacial para cuantificar la esquiabilidad y la afluencia turística en el Pirineo bajo distintos escenarios de cambio climático", financed by the Comunidad de Trabajo de los Pirineos. 


\section{References}

Abegg, B.,1996. Klimaänderung und Tourismus. Schlussbericht NFP 31. vdf Hochschulverlag AG an der ETH, Zürich.

Abegg, B., Agrawala, S., Crick F., de Montfalcon, A., 2007. Climate change impacts and adaptation in winter season. In: Agrawala S (Ed) Climate change in European Alps: adapting winter tourism and natural hazards management. Organisation for Economic Co-operation and Development (OECD), Paris, pp 25-60.

Baltas, EA., 2007. Impact of climate change on the hydrological regime and water resources in the basin of Siatista. International Journal of Water Resources

Development 23: 501-518.

Barnett,TP., Adam, JC., Lettenmaier, DP., 2005. Potential impacts of a warming climate on water availability in snow-dominated regions. Nature 438: 3003-309.

Beniston, M., Keller, F., Koffi, B., Goyette, S., 2003b. Estimates of snow accumulation and volume in the Swiss Alps under changing climatic conditions. Theoretical and Applied Climatology 76: 125-140.

Breiling, M., Charamza, P., 1999. The impact of global warming on winter tourism and skiing: a regionalised model for Austrian snow conditions. Regional Environmental Change 1(1): 4-14.

Dar, RA., Rashid, I., Romshoo, SA., Mazari, A., 2013. Sustainability of winter tourism in a changing climate over Kashmir Himalaya. Environmental monitoring assessment. DOI 10.1007/s10661-013-3559-7.

Dawson, J., Scott, D., 2007. Climate change vulnerability in the Vermont ski tourism sector. Annals Leisure research 10: 550-571.

Dawson, J., Scott, D., McBoyle, G., 2009. Climate change analogue analysis of ski tourism in the northeastern USA. Climate research 39: 1-9.

Dawson, J., Scott, D., 2010. Systems of analysis of climate change vulnerability for the US northeast ski sector. Tourism Hospitality Planned Development 7: 219-235.

Dawson, J., Scott, D., 2013. Managing for climate change in the alpine ski sector. Tourism Management 35: 244-254.

Demiroglu, OC., 2000. Impact of Climate Change on Winter Tourism: A Case of Turkish Ski Resorts. Unpublished Master's Thesis, Department of Geography and Economic History, Umeå University, Sweden.

Dequé, M., Rowell, DP., Luethi D et al., 2007. An intercomparison of regional climate simulations for Europe: assessing uncertainties in model projections. Climatic change 81: $53-70$.

Elsasser, H., Bürky, R., 2002. Climate change as a threat to tourism in the Alps. Climate research 20: 253-257. 
Endler, C., Matzarakis, A., 2011. Climatic potential for tourism in the Black Forest, Germany- Winter season. International Journal of Biometeorology 55:339-351.

Estudio sobre el sector de la nieve en Aragón. Síntesis de diagnóstico y escenarios de futuro, documento 4.1 2009. Gobierno de Aragón.

EURAC .,2007. "Impacts of Climate Change on winter tourism in the Italian Alps" ClimChalp Report.

Fauve, M., Rhyner, H., Schneebeli, M., (2002). Preparation and Maintenance of Pistes: Handbook for Practitioners. Ed. Swiss Federal Institute for Snow and Avalanche Research, Davos, 133 pp.

Fukushima, T., Kureha, M., Ozaki, N., Fujimori, Y., Harasawa, H., 2002. Influences of air temperature change on leisure industries: case study on ski activities. Mitigation and Adaptation Strategies for Global Change 7: 173-189.

Galloway, R., 1988. The potential impact of climate changes on Australian ski fields. In Greenhouse: Planning for Climatic Change, ed. G. Pearlman, 428-437. Melbourne, AU: CSIRO.

Gonset, C., 2013. Impact of snow variability on the Swiss winter tourism sector: implications in an era of climate change. Climate change 119: 307-320.

Harpold, A., Brooks, P., Rajagopal, S., Heidbuchel, I., Jardine, A., Stielstra, S., 2012. Changes in snowpack accumulation and ablation in the intermountain west, Water Resources Research 48, W11501, doi:10.1029/2012WR011949.

Hendrikx, J., Zammit, C., Hreinsson, ÖE., Becken, S., 2013. A comparative assessment of the potential impact of climate change on the ski industry in New Zealand and Australia. Climate change 119: 965-978.

Heo, I., Lee, S., 2008. The impact of climate changes on ski industries in South KoreaIn the Case of the Yongpyong Ski Resort. Journal of de Korean Geographical Society 43: 715-727.

Hopkins, D,. 2014. The sustainability of climate change adaptation strategies in New Zealand's ski industry: a range of stakeholders perceptions. Journal of sustainable tourism 22: 107-126.

Koenig, U., Abegg, B., 1997. Impacts of climate change on winter tourism in the Swiss Alps. Journal of sustainable tourism 5: 46-58

Koenig, U.,1998. Tourism in a Warmer World: Implications of Climate Change Due to Enhanced Greenhouse Effect for the Ski Industry in the Australian Alps. Wirtschaftsgeographie und Raumplanung 28, University of Zuerich.

Lamothe, M., Périard, D.,1988. Implications of climate change for Downhill Skiing in Quebec. Climate change Digest, Atmospheric Environment Service, Downs view, 88103. 
Lasanta, T., Laguna, M., Vicente-Serrano, SM., 2007. Do tourism-based ski resorts contribute to the homogeneous development of the mediterranean mountains? A case study in the Central Spanish Pyrenees. Tourism management 28: 1326-1339.

Laternser, M., Schneebeli, M., 2003. Long-term snow climate trends of the Swiss Alps (1931-99). International Journal of Climatology 23: 733-750.

Lipski, S., McBoyle, G.,1991. The impact of global warming on downhill skiing in Michigan. East Lakes Geographer 26:37-51.

López-Moreno, JI., 2005. Recent variations of snowpack depth in the Central Spanish Pyrenees. Arctic, Antarctic, and Alpine Research 37 (2): 253-260.

López-Moreno, JI., Goyette, S., Beniston, M., 2008. Climate change prediction over complex areas: spatial variability of uncertainties and expected changes over the Pyrenees from a set of regional climate models. International Journal of Climatology 28 (11):1535-1550.

López-Moreno, JI., Goyette, S., Beniston, M., 2009. Impacts of climate change on snowpack in the Pyrenees: Horizontal spatial variability and vertical gradients. Journal of Hydrology 374: 384-396.

López-Moreno, JI., Pomeroy, JW., Revuelto J., Vicente-Serrano SM., 2012. Response of snow processes to climate change: spatial variability in a small basin in the Spanish Pyrenees. Hydrological processes 27: 2637-2650.

Marty, C., 2008. Regime shift of snow days in Switzerland. Geophysical Research Letters 35 L12501, doi:10.1029/2008GL033998.

McBoyle, G., Wall, G., 1987. The impact of $\mathrm{CO}_{2}$ induced warming on downhill skiing in Laurentians. Cahiers de géographie du Quebec 31: 39-50.

McBoyle, G., Wall, G., 1992. Great Lakes skiing and climate change. In Gill A, Hartman R (ed) Mountain resort development. Simon Fraser University, Centre for Tourism Policy and Research, Burnaby, BC, 71-81.

Mercalli, L., Acordon, V., Cat Berro, D., Di Napoli, G., 2006. Cambiamenti climatici in Valle d' Aosta. Opportunità e strategie di risposta. Ed. SMS, Bussoleno. X+159 pp.

Mercalli, L., Morra di Cela, U., Cremonese, E., Agnesod, E., Tornato, S., Piccini, C., 2007. Cambiamenti climatici e ambienti nivo-glaciali: scenari e prospettive di adattamento. Conferenza nazionale Cambiamenti climatici. Saint-Vicent (Vall d'Aosta) 2-3 luglio 2007.

Moen, J., Fredman, P., 2007. Effects of climate change on alpine skiing in Sweden. Journal of sustainable tourism 15: 418-437.

Morrison, C., Pickering, CM., 2013. Perceptions of climate change impacts, adaptation and limits to adaption in the Australian Alps: the ski-tourism industry and key stakeholders. Journal of sustainable tourism 21: 173-191.

Nesje, A., Dahl, SO., 2000. Glaciers and Environmental Change. Arnold Publishers: London, 216 pp. 
OECD., 2006. Climate Change in the European Alps: Adapting Winter Tourism and Natural Hazards Management, Agrawala, S (ed.). OECD Publishing: Paris, France, 136.

Pickering, M., Buckley, R., 2010. Climate response by the ski industry: The Shortcomings of Snowmaking for Australian Resorts. AMBIO 39: 430-438.

Pons-Pons, M., Johnson, PA., Rosas-Casals, M., Sureda, B., Jover, E., 2012. Modelling climate change effects on winter ski tourism in Andorra. Climate research, 54: 197-207. Ribalaygua, J., Pino, MR., Pórtoles, J., Roldán, E., et al., 2013. Climate change scenarios for temperature and precipitation in Aragón (Spain). Science of the total environment 463-464 (2013) 1015-1030.

Scherrer, SC., Appenzeller, C., Laternser, M., 2004. Trends in Swiss Alpine snow days: the role of local- and large-scale climate variability. Geophysical Research Letters 31:L13215. DOI: 10.1029/2004GL020255.

Scott, D., McBoyle, G., Mills, B., 2003. Climate change and the skiing industry in southern Ontario (Canada): Exploring the importance of snowmaking as a technical adaptation. Climate research 23:171-181.

Scott, D., 2006. Global Environmental Change and Mountain Tourism. In Gössling,S and Hall, C.M (eds), Tourism and Global Environmental Change (pp. 54-75). London, New York: Routledge.

Scott, D., McBoyle, G., Minogue, A., Mills, B., 2006. Climate change and the sustainability of ski-based tourism in eastern North America: a reassessment. Journal of sustainable tourism 14: 376-398.

Scott, D., McBoyle, G., Minogue, A., 2007. Climate change and Quebec's ski industry. Global Environmental Change 17: 181-190.

Scott, D., Dawson, J., Jones, B., 2008. Climate change vulnerability of the US Northeast winter recreation- Tourism sector. Mitigation Adaptation Strategies for Global Change 13:577-596.

Steiger, R., Mayer, M., 2008. Snowmaking and climate change: Future options for snow production in Tyrolean ski resorts. Mountain research and development, 25(3-4): 292298.

Steiger, R., 2010. The impact of climate change on ski season length and snowmaking requirements in Tyrol, Austria. Climate research 43: 251-262.

Steiger, R., 2011. The impact of climate change on ski touristic demand using an analogue approach. In K. Weiermair, H. Pechlaner, A. Strobl, and M. Elmi (Eds), Coping with global climate change. Strategies, policies and measures for the tourism industry (pp. 247-256). Innsbruck: Innsbruck University Press.

Steiger, R., 2012. Scenarios for skiing tourism in Austria: Integrating demographics with an analysis of climate change. Journal of Sustainable tourism, DOI:10.1080/09669582.2012.680464. 
Steiger, R., Abegg, B., 2013. The sensitivity of Austrian Ski areas to climate change. Tourism, planning and development, 480-493. DOI: 10.1080/21568316.2013.804431

Tranos, E., Davoudi, S., 2014. The regional impact of climate change on winter tourism in Europe. Tourism planning and development. DOI: 10.1080/21568316.2013.864992.

Uhlmann, B., Goyette, S., Beniston, M., 2009. Sensitivity analysis of snow patterns in Swiss ski resorts to shifts in temperature, precipitation and humidity under conditions of climate change. International journal of climatology 29:1048-1055.

Valt, M., Cagnati, A., Crepaz, A., Marigo, G.,2005. Snow precipitation in the last years on Italian Alps. Hrvatski Meteoroloski Casopis 40: 654-657.

Vanham, D., Fleischhacker, E., Rauch, W., 2009. Impact of snowmaking on alpine water resources management under present and climate change conditions. Water Science and Technology 59: 1793-1801.

Vojtek, M., Faško, P., Št’astný, P., 2003. Some selected snow climate trends in Slovakia with respect to altitude. Acta Met. Univ., Vol. XXXII, 17-27.

Witmer, U., 1986. Recording, procesing and mapping of snow data in Switzerland. Bern: Institute of geography, University of Bern. 


\begin{tabular}{|c|c|c|c|c|c|c|c|c|}
\hline Country & Region & $\begin{array}{l}\text { Climate change } \\
\text { scenario used }\end{array}$ & $\begin{array}{c}\text { Minimum } \\
\text { altitude } \\
\text { snow-reliable } \\
\text { under CC } \\
\end{array}$ & $\begin{array}{l}\text { Snow pack } \\
\text { duration }\end{array}$ & Snow depth & $\begin{array}{l}\text { Loss of ski } \\
\text { season }\end{array}$ & Others impacts & Study \\
\hline Switzerland & Alps & $\begin{array}{c}+0,3^{\circ} \mathrm{C} \\
+2^{\circ} \mathrm{C}, \text { no change } \mathrm{p}^{*} \\
\text { (IPCC) }\end{array}$ & $\begin{array}{l}1200 \mathrm{~m} \\
1500 \mathrm{~m}\end{array}$ & - & - & - & $\begin{array}{l}63 \% \text { resorts remain } \\
\text { reliable }\end{array}$ & $\begin{array}{c}\text { Koenig and Abegg } \\
\text { (1997) }\end{array}$ \\
\hline \multirow[t]{2}{*}{ Switzerland } & Alps & $\begin{array}{l}+1{ }^{\circ} \mathrm{C} \\
+2{ }^{\circ} \mathrm{C} \\
+4{ }^{\circ} \mathrm{C}\end{array}$ & & & & & $\begin{array}{l}\text { resorts remain reliable : } \\
+1{ }^{\circ} \mathrm{C}(142 \text { of } 164) \\
+2{ }^{\circ} \mathrm{C}(129 \text { of } 164) \\
+4{ }^{\circ} \mathrm{C}(78 \text { of } 164)\end{array}$ & Abegg et al, 2007 \\
\hline & Alps & $\begin{array}{c}\mathrm{A} 2+4^{\circ} \mathrm{C}(2071- \\
2100)+1(\mathrm{~mm} / \text { day }) \\
\text { precipitation } \\
(\mathrm{HIRHAM} 4 ; \mathrm{RCM})\end{array}$ & - & $\begin{array}{l}-50 \text { days } \\
(2000 \mathrm{~m}) ;- \\
110 \text { days } \\
(1000 \mathrm{~m})\end{array}$ & $-55 \%$ & - & $\begin{array}{l}\text { Reduction snow fall - } \\
90 \%(1000 \mathrm{~m}) ; \quad-45- \\
60 \%(2000 \mathrm{~m}) ; \\
30-40 \%(3000 \mathrm{~m})\end{array}$ & $\begin{array}{l}\text { Beniston et al. } \\
\quad \text { (2003) }\end{array}$ \\
\hline Italy & Alps & $\begin{array}{c}+1^{\circ} \mathrm{C} ;+2^{\circ} \mathrm{C} ;+4^{\circ} \mathrm{C} \\
\text { no change } \mathrm{p}\end{array}$ & $\begin{array}{l}1650 \mathrm{~m} ; 1800 \mathrm{~m} \\
; 2100 \mathrm{~m}\end{array}$ & $\begin{array}{c}+1^{\circ} \mathrm{C}=-35 \% \\
(1400 \mathrm{~m}) ;- \\
15 \%(1800 \mathrm{~m}) \\
;-12 \% \\
2300 \mathrm{~m} \\
\end{array}$ & - & - & $\begin{array}{c}\text { - } 36 \text { stations reliable; - } \\
79 \text { reliable stations ; - } \\
137 \mathrm{rs}\end{array}$ & $\begin{array}{l}\text { Mercalli et al. } \\
\text { (2007); EURAC } \\
\text { (2007) }\end{array}$ \\
\hline \multirow[t]{2}{*}{ Austria } & Alps & $+2^{\circ} \mathrm{C}$ no change $\mathrm{p}$ & - & - & - & - & - & $\begin{array}{c}\text { Breiling and } \\
\text { Charamza (1999) }\end{array}$ \\
\hline & Alps & $\begin{array}{l}\mathrm{A} 1+1^{\circ} \mathrm{C} \\
\mathrm{B} 1+2^{\circ} \mathrm{C} \\
\mathrm{A} 2+4^{\circ} \mathrm{C}\end{array}$ & - & - & - & - & $\begin{array}{l}\text { Ski reliable areas } \\
\quad+1^{\circ}-19 \% \\
+2^{\circ}-43 \% \\
+4^{\circ}-82 \%\end{array}$ & $\begin{array}{c}\text { Steiger and Abegg } \\
(2013)\end{array}$ \\
\hline Sweden & Sälen & $\begin{array}{c}\text { RE-A2 }+5^{\circ} \mathrm{C} \\
45^{\circ} \mathrm{p} \\
\text { RH-B2 }+2.5^{\circ} \mathrm{C}+15 \% \\
\mathrm{p}(2070-2100)\end{array}$ & - & - & - & $\begin{array}{l}-96 \text { days (A2) } \\
-64 \text { days (B2) }\end{array}$ & $\begin{array}{c}\text { Reduction snow fall } \\
-66 \% \text { (A2) } \\
-44 \% \text { (B2) }\end{array}$ & $\begin{array}{l}\text { Moen and Fredman } \\
(2007)\end{array}$ \\
\hline Spain/ France & Pyrenees & $\begin{array}{c}\mathrm{A} 2+3,1^{\circ} \mathrm{C}-1,6 \% \mathrm{p} \\
\mathrm{B} 2+1,3^{\circ} \mathrm{C}+11 \% \mathrm{p} \\
(2070- \\
2100)(\mathrm{HIRHAM} ; \\
\text { RCM) }\end{array}$ & - & $\begin{array}{c}\mathrm{A} 2- \\
78 \%(1500 \mathrm{~m}) \\
-20 \%(3000 \mathrm{~m}) \\
\mathrm{B} 2-44 \% \\
(1500 \mathrm{~m})- \\
11 \%(3000 \mathrm{~m})\end{array}$ & $\begin{array}{c}\mathrm{A} 2-70 \% \\
(1500 \mathrm{~m}) \\
11 \%(3000 \mathrm{~m}) \\
\mathrm{B} 2- \\
32 \%(1500 \mathrm{~m}) ;- \\
5 \%(3000 \mathrm{~m})\end{array}$ & - & - & $\begin{array}{c}\text { López-Moreno et } \\
\text { al. (2009) }\end{array}$ \\
\hline
\end{tabular}




\begin{tabular}{|c|c|c|c|c|c|c|c|c|}
\hline Country & Region & $\begin{array}{l}\text { Climate change } \\
\text { scenario used }\end{array}$ & $\begin{array}{c}\text { Minimum } \\
\text { altitude } \\
\text { snow-reliable } \\
\text { under CC }\end{array}$ & $\begin{array}{l}\text { Snow pack } \\
\text { duration }\end{array}$ & Snow depth & $\begin{array}{l}\text { Loss of ski } \\
\text { season }\end{array}$ & Others impacts & Study \\
\hline Spain & $\begin{array}{l}\text { Aragón } \\
\text { Pyrenees }\end{array}$ & $\begin{array}{c}\mathrm{A} 2+5^{\circ} \mathrm{C}-20 \% \mathrm{p} \quad \mathrm{B} 2 \\
+4^{\circ} \mathrm{C}-10 \% \mathrm{p} \\
(2040-2100) \\
(\mathrm{HadCM} 3 ; \mathrm{RCM})\end{array}$ & $1750-1800 \mathrm{~m}$ & - & - & - & & $\begin{array}{l}\text { Estudio sector } \\
\text { nieve Aragón } \\
\quad(2009)\end{array}$ \\
\hline Andorra & Pyrenees & $\begin{array}{c}(\mathrm{HadCM} 3 ; \mathrm{RCM}) \\
\mathrm{B} 2+2^{\circ} \mathrm{A} 2+4^{\circ}\end{array}$ & - & - & - & $\begin{array}{l}+2^{\circ} \quad-30 \% \quad(\mathrm{Pal} \\
\text { Arinsal) } \\
-3 \% \text { (Arcalís) } \\
0 \% \text { (GrandValira) } \\
+4^{\mathrm{o}}-95 \% \text { (Pal- } \\
\text { Arinsal), - } 27 \% \\
\text { (Arcalis) - } 17 \% \\
\text { (GrandValira) }\end{array}$ & ) & Pons et al. (2012) \\
\hline \multirow[t]{2}{*}{ Canada } & Quebec & $\begin{array}{c}\text { A1 CCSRNIES B2 } \\
\text { NCARPCM }(2020- \\
2050)\end{array}$ & - & - & $\begin{array}{c}\text { A1 }-29 \%(2020) ; \\
-75 \%(2050) \\
\text { B2-8\%(2020); } \\
-26 \%(2050)\end{array}$ & $\begin{array}{cc}\text { A1 }-15 \%(2020) ; \\
-30 \%(2050) & \text { B2 } \\
-2 \%(2020) ; & -7 \% \\
(2050) & \end{array}$ & $\begin{array}{c}\text { snowmaking } \\
\text { requirements A1 } \\
+43 \%(2020)+131 \% \\
(2050) \mathrm{B} 2+15 \%(2020) \\
+30 \%(2050)\end{array}$ & Scott et al. (2007) \\
\hline & Ontario & $\begin{array}{c}\text { CGCM1-IS92a; } \\
\text { HadCM3-IS92a; } \\
\text { CCSR-IS92a; CSIRO- } \\
\text { A2 ; CGCM2-B2; } \\
\text { HadCM3-B2 } \\
(2020-2050-2080)\end{array}$ & - & - & - & $\begin{array}{c}\text { CGCM1-IS92a - } \\
\text { 48\% (2080); } \\
\text { HadCM3-IS92a - } \\
\text { 37\%(2080); } \\
\text { CCSR-IS92a -45\% } \\
\text { (2080); CSIRO-A2 } \\
\text {-50\%(2080) } \\
\text { HadCM3 B2 - } \\
\text { 11\% (2080) } \\
\text { CGCM2-B2 - } \\
\text { 19\% (2080) }\end{array}$ & $\begin{array}{c}\text { snowmaking } \\
\text { requirements }(2080) \\
\text { CGCM1-IS92a }+380 \% ; \\
\text { HadCM3-IS92a }+312 \% \text {; } \\
\text { CCSR-IS92a +401\%; } \\
\text { CSIRO-A2 }+380 \% ; \\
\text { CGCM2-B2 +267\%; } \\
\text { HadCM3-B2 + } 191 \%\end{array}$ & Scott et al. (2003) \\
\hline
\end{tabular}




\begin{tabular}{|c|c|c|c|c|c|c|c|c|}
\hline Country & Region & $\begin{array}{l}\text { Climate change } \\
\text { scenario used }\end{array}$ & $\begin{array}{c}\text { Minimum } \\
\text { altitude } \\
\text { snow-reliable } \\
\text { under CC }\end{array}$ & $\begin{array}{c}\text { Snow pack } \\
\text { duration }\end{array}$ & Snow depth & $\begin{array}{l}\text { Loss of ski } \\
\text { season }\end{array}$ & Others impacts & Study \\
\hline EEUU & Northeast & $\begin{array}{c}\mathrm{A} 1+4,4^{\circ} \mathrm{C}+30 \% \mathrm{p} \\
\mathrm{B} 1+2,7^{\circ} \mathrm{C}+20 \% \mathrm{p} \\
(2040-2069)\end{array}$ & - & - & $-40 \%$ & $\begin{array}{l}\text { A1 -11\% (-15d) } \\
\text { B1 -4\% (-5d) }\end{array}$ & $\begin{array}{c}\text { Drop in visits } \quad \mathrm{A} 1 \text { - } \\
11,6 \% \mathrm{~B} 1-10,8 \%\end{array}$ & $\begin{array}{l}\text { Dawson et al. } \\
\quad \text { (2009) }\end{array}$ \\
\hline & Northeast & $\begin{array}{c}\mathrm{A} 1 \\
\mathrm{~B} 1 \\
(2010-2039 ; 2040- \\
2069 ; 2070-2099)\end{array}$ & - & - & - & & $\begin{array}{c}\text { Snow reliable Ski areas } \\
\text { under } 100 \text { d rules: } \\
2010-203955 \%(\mathrm{~B} 1) \\
54 \%(\mathrm{~A} 1) \\
2040-2069 \\
54 \%(\mathrm{~B} 1), 40 \%(\mathrm{~A} 1) \\
2070-2099 \\
45 \%(\mathrm{~B} 1) \\
29 \%(\mathrm{~A} 1)\end{array}$ & $\begin{array}{c}\text { Dawson and Scott } \\
\text { (2013) }\end{array}$ \\
\hline Turkey & $\begin{array}{l}\text { General } \\
\text { study }\end{array}$ & $\begin{array}{c}+1^{\circ}(2025) ;+2^{\circ} \\
(2050)+4^{\circ}(2100)\end{array}$ & $\begin{array}{l}2200 \mathrm{~m}(2025) \\
2400(2050) \\
2700 \mathrm{~m}(2100)\end{array}$ & - & - & - & $\begin{array}{c}\text { Snow reliable } \mathrm{n}^{\mathrm{o}} \mathrm{ski} \\
\text { areas }-8(2025)-10 \\
(2050)-12(2100)\end{array}$ & Demiroglu (2000) \\
\hline Japan & $\begin{array}{l}\text { General } \\
\text { study }\end{array}$ & $+3^{\circ} \mathrm{C}$ no change $\mathrm{p}$ & - & - & - & - & $\begin{array}{l}\text { Drop in visits }-30 \% ;- \\
50 \% \text { in southern regions }\end{array}$ & $\begin{array}{l}\text { Fukushima et al. } \\
\qquad(2002)\end{array}$ \\
\hline $\begin{array}{l}\text { South } \\
\text { Corea }\end{array}$ & $\begin{array}{c}\text { Yongpyong } \\
\text { resort }\end{array}$ & A1B (2011-2100) & - & - & - & $\begin{array}{l}-15 \text { days } \quad(2010- \\
2030) \\
-36 \text { days } \quad(2030- \\
2060) \\
-59 \text { days }(2060- \\
2090)\end{array}$ & $\begin{array}{l}\begin{array}{l}\text { Suitable days for } \\
\text { snowmaking }\end{array} \\
\text {-21days(50 days) 2008, } \\
\text { 31 days 2060-2090) }\end{array}$ & Heo and Lee (2008) \\
\hline Australia & $\begin{array}{l}\text { Australian } \\
\text { Alps }\end{array}$ & $\begin{array}{c}+0,3^{\circ} \mathrm{C}+1,3^{\circ} \mathrm{C} \\
(2030)+0,6^{\circ} \mathrm{C}+3,4^{\circ} \mathrm{C} \\
(2070)\end{array}$ & - & - & - & - & $\begin{array}{c}\text { Snow reliable ski areas } \\
+0.3^{\circ} \mathrm{C}-1(9)+1.3^{\circ} \mathrm{C}-8(9) \\
(2030) \\
+0.6^{\circ} \mathrm{C}-3(9) \\
+3.4^{\circ} \mathrm{C}-9(9) \\
(2070)\end{array}$ & Koenig (1998) \\
\hline
\end{tabular}




\begin{tabular}{|c|c|c|c|c|c|c|c|c|}
\hline Country & Region & $\begin{array}{l}\text { Climate change } \\
\text { scenario used }\end{array}$ & $\begin{array}{c}\text { Minimum } \\
\text { altitude } \\
\text { snow-reliable } \\
\text { under CC }\end{array}$ & $\begin{array}{l}\text { Snow pack } \\
\text { duration }\end{array}$ & Snow depth & $\begin{array}{l}\text { Loss of ski } \\
\text { season }\end{array}$ & Others impacts & Study \\
\hline & $\begin{array}{l}\text { Australian } \\
\text { Alps }\end{array}$ & $+1^{\circ} \mathrm{C}-8 \% \mathrm{p}(2020)$ & - & $\begin{array}{c}35 \% \\
\text { locations with } \\
\text { at least } \\
70 \text { days }>1 \mathrm{~cm}\end{array}$ & $-60 \%$ & - & & $\begin{array}{l}\text { Pickering and } \\
\text { Bukley (2010) }\end{array}$ \\
\hline & $\begin{array}{c}\text { Australian } \\
\text { Alps }\end{array}$ & $\begin{array}{c}\text { A1 (2030-2049) } \\
(2080-2099)\end{array}$ & - & $\begin{array}{l}\text { Days with } \\
\text { snow depth } \\
\geq 30 \mathrm{~cm} \\
\text { duration will } \\
\text { be reduced } \\
\text { from } 124 \text { will } \\
\text { be reduced to } \\
85 \text { by } 2040 \\
\text { and } 21 \text { days } \\
\text { for } 2090 .\end{array}$ & $\begin{array}{c}2040-22 \%- \\
33 \% \\
2090-43 \%- \\
62 \%\end{array}$ & - & - & $\begin{array}{l}\text { Hendrix et al. } \\
\text { (2013) }\end{array}$ \\
\hline New Zealand & & $\begin{array}{l}\text { A1 (2030-2049) } \\
(2080-2099)\end{array}$ & - & $\begin{array}{l}\text { Days with } \\
\text { snow depth } \\
\geq 30 \text { cm } \\
\text { duration will } \\
\text { be reduced } \\
\text { from } 125 \text { days } \\
\text { to } 111 \text { in } \\
2040 \text {, and } 85 \\
\text { to } 2090\end{array}$ & $\begin{array}{c}2040-0 \%- \\
10 \% \\
2090-46 \%- \\
76 \%\end{array}$ & - & - & $\begin{array}{l}\text { Hendrix et al. } \\
\text { (2013) }\end{array}$ \\
\hline
\end{tabular}

$* p=$ precipitation 
Gilaberte Búrdalo $\mathrm{M}$ is a Ph.D student candidate in Environmental Management at San Jorge University (Spain). She completed a Master's degree in Territorial and Environmental Management. She is also a member of the GIMACES research group, and collaborates in the research group "Environmental Geoprocesses and Global Change" in the CSIC Instituto Pirenaico de Ecología (Pyrenean Institute of Ecology).

Dr F. López-Martín is manager of territorial information center at the Aragón government. Member of GIMACES research group and lecturer in the Environmental Management for Business Master's degree program at San Jorge University (Spain). He has led research on urban climate, citizen participation, territorial policy and environmental education.

Dra Pino-Otín MR is the Associate Dean of Research at San Jorge University and the head of the GIMACES research group. As Director of the Environment Institute she participates as a lecturer in the Environmental Management for Business Master's degree program where she teaches Research Methodology and Documentary Sources.Particular research interests include: climate change, climatic scenarios and ecology.

Dr López-Moreno JI is Senior Research Scientist in the Geoenvironmental Processes and Global Change department at the CSIC Instituto Pirenaico de Ecología (Pyrenean Institute of Ecology). He has lead several projects in hydrology processes. Particular research interests include: snow hydrology, climatic change, water resources management and recent evolution of the Pyrenean glaciers. 